investigated by the most senior members of the Treasury. Newton then put all of his energies into preparing a careful case against his rival, personally interrogating a number of Chaloner's former associates, and at a trial in March 1699 secured a conviction against him for counterfeiting. Chaloner feigned madness for a time - his final sham - but was hanged the same month.

Newton and the Counterfeiter contains the odd error of fact, and Levenson is on sticky historical ground with his claims about the wider contexts of the events he describes. A more conspicuous drawback is the author's failure to consider Newton's feud with Chaloner in the light of his battles with other luminaries of that era, such as Robert Hooke and Gottfried Leibniz, or even Newton's relentless denunciation of the fourth-century Saint Athanasius - in his view, the propagator of the corrupt doctrine of the Holy Trinity. Privately, Newton expended a vast amount of time examining the morals and actions of people such as Athanasius, and finding them guilty of crimes against Christianity.
Newton may have known next to nothing about prosecuting clippers and coiners, as Levenson correctly notes, but once it became personal, Chaloner stood little chance against a man who spent much of his life cutting much larger intellectual heavyweights down to size.

Robert Iliffe is professor of intellectual history and the history of science in the Department of History, University of Sussex, Brighton BN1 9RH, UK; author of Newton: A Very Short Introduction; and editorial director of the Newton Project (www.newtonproject.sussex.ac.uk).

\title{
Florence's observatory restored
}

\section{Torrino della Specola \\ Museum of Natural History, Florence Opens 7 November}

Newly restored, an elegant eighteenth-century astronomical observatory in Florence, Italy, reopens to the public this week after 135 years.

Its builder, Italian polymath Felice Fontana, had rushed from Pisa across the hills of Tuscany, bursting with zeal. The Grand Duke Pietro Leopardo had chosen him to direct his new Museum of Physics and Natural History in Florence, which opened to the public in 1775 . Fontana now had carte blanche to realize his Utopian dream: a museum in which all that was known of nature could be brought into a single building for the edification of the people, and for scientists to make yet more discoveries. It would be a pinnacle of Enlightenment endeavour, and Fontana intended it to be on a par with Florence's unequalled fine-art collections.

The Grand Duke commissioned the restructuring of the medieval Torrigiani palace for the museum, ensuring its prominent position between two Renaissance landmarks: the monumental Pitti palace and the formal, sculpture-filled Boboli gardens.

Fontana threw himself into acquiring collections based on natural history, botany, mineralogy and more - as well as commissioning the wax anatomical and botanical models for which Florence is justly famous (see Nature 452, 414; 2008). Astronomy, neglected by the city since Galileo's death there in 1642, was to be a major activity. So the Torrigiani palace was reinforced to bear the weight of a 35-metre-high observation tower, the Torrino della Specola.

This was an unpopular move. Even the observatory's first director, Domenico de Vecchi, was outspokenly critical of its logistical virtues. "For all its elegance, it is not the most favourable for observations, nor the most comfortable for observers," he wrote in 1808, a year after he was appointed director.

Indeed, few astronomers approved. The modern trend was to build observatories away from towns and above the mist, on top of hills where there was plenty of space. The observatory tower was simply cramped - the architect had built it without consulting astronomers and had failed to provide space for them to

The observatory tower remained closed, but has now been renovated to its original glory. It reopens as an extension to the museum on 7 November, in this International Year of Astronomy that marks the 400th anniversary of Galileo's first observations with a telescope.

There are three good reasons to visit. First is the exhibition. Paying homage to Fontana's vision of the all-inclusive scientific centre, the tower displays representative artefacts from the original collections - ornaments acquired by Captain James Cook; two bewilderingly life-

like magnolia and lotus flowers made of wax; a Medici collection of worked gemstones; an ancient herbarium; some fossils, a pair of taxidermically prepared lion monkeys; a few historic telescopes and a couple of still-life paintings by Bartolomeo Bimbi. The displays are not extensive - the space hasn't got any larger in the past two centuries - but they are fine examples.

Second, the architecture is a work of art - octagonal rooms, gracious windows and elegant, narrow spiral staircases. Most astounding is the Meridian Room, whose supporting arches are stuccoed with slender storks in the act of

retire to their books or writing tables. Annoyingly, the perfect hill was there for the taking - Arcetri, overlooking Florence, where Galileo had made his last home. Galileo's residence, known as Il Gioiello, or The Jewel, was restored and reopened earlier this year.

But Fontana was unshakably wedded to his vision of the all-encompassing museum and science centre. He resisted incessant calls to relocate the observatory. Fontana died in 1805 , but more than 60 years passed before pragmatism finally won out and in 1872 , the astronomers moved to a new observatory on Arcetri, which still operates today. By then, Fontana's Utopia was being broken up, with many collections being distributed to other sites in Florence, including the university. Only the natural-history and anatomical collections remained in the museum. taking flight. A marble meridian inlaid into the floor, decorated in copper and silver, indicates the hour and time of year. When astronomers used this room for observations, a narrow slit in the walls and roof could be opened to expose a $180^{\circ}$ slice of the sky. Eight large windows and an outside terrace allowed an unobstructed view of the whole sky.

The third reason to visit the tower is its superb location. Its elevation allows a unique and commanding view of one of the world's most beautiful cities - a panorama that has not been seen by the public for 135 years.

Alison Abbott is Nature's senior European correspondent.

For more details on the observatory tower, see www.msn.unifi.it. See go.nature.com/V52qT5 for articles in the hidden treasures series. 


\section{In Retrospect: The earliest picture of evolution?}

\section{Ideas about the mutability of species may have been part of Enlightenment imagery before Lamarck.}

De anima brutorum commentaria
(Commentary on the Soul of Animals)
by Francesco Maria Soldini
Gaetano Cambiagi: 1776

Illustrations can convey scientific ideas as effectively as the written word. It is widely accepted that there was no graphical representation of the evolution of species before 1800 , when the naturalist Jean-Baptiste Lamarck added the axis of time to his classification tree diagrams. However, I have found illustrations in a little-known book written by the Carmelite monk Francesco Maria Soldini that predate Lamarck's imagery. Plates in the book, published in Florence in 1776, clearly depict life emerging from the sea onto land.

Written in Latin, De anima brutorum commentaria is one of many books printed in the sixteenth and eighteenth centuries on the concept that animals have a soul. Soldini anchors his arguments to the writings of great philosophers from ancient times, such as Aristotle, and to scripture, especially the Book of Genesis. He was also influenced by contemporaries, notably Immanuel Kant, Gottfried Leibniz, Étienne Bonnot de Condillac and PierreLouis Moreau de Maupertuis. The book is a very rare volume and its scientific significance has escaped notice until now.

Soldini's book is embellished with eight stunning engravings by an unknown artist that depict natural scenes and animals, bound at the beginning of each chapter. The plates are printed in blue or red to contrast with the elegantly decorated initial letter of the text. But the iconographical content of the images is independent from the writing: many of the animal pictures are taken from the wood carvings of other treatises on zoology, such as those by the sixteenth-century naturalists Ulisse Aldrovandi and Conrad Gesner, which are not cited by Soldini. It is therefore likely that the plates were added separately to decorate the book, which was produced by Gaetano Cambiagi, typographer to the Grand Duke of Tuscany.

In two of the eight plates, the engraver portrays marine animals, mainly crustaceans, leaving the water and colonizing land. These images are reminiscent of the 'Neptunian' theory of Earth described by the French literary scholar and diplomat Benoît de Maillet (1656-1738). In his book Telliamed, which circulated for decades before being posthumously published in 1748, de Maillet explains how Earth was once entirely covered by water. He proposes that life began in the water in the form of minuscule seeds that joined together to create all aquatic forms, from which all terrestrial and winged creatures were then derived. In his opinion, all plants and ani-

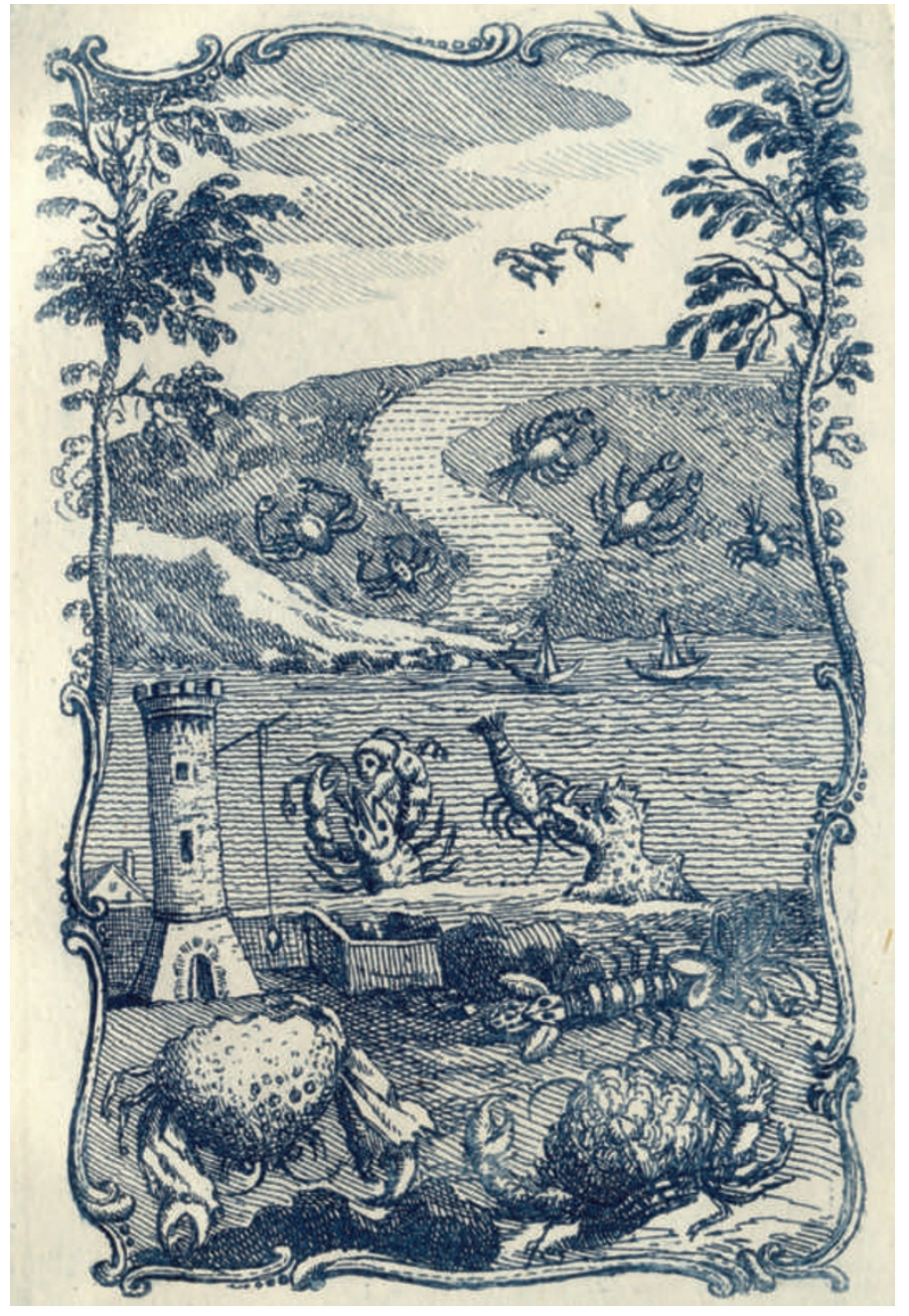

An engraving published in 1776, 83 years before On the Origin of Species. mals would have analogous examples among the aquatic specimens. The plates do indeed display marine animals that have parallels with species living on land, even in their names, such as the mantis shrimp and the fantastical marine rhinoceros. Yet Soldini makes no mention of either Telliamed or de Maillet in his otherwise highly referenced book.

A third plate represents images of fish taken from the iconography of the sixteenth century. They swim holding their heads above water with birds flying above. Such representations follow another de Maillet idea, that animals are derived from two basic types: the flying ones that live between the sea floor and the surface, which today is known as the pelagic zone, and the creatures that crawl on the sea floor, or benthic zone. Birds would have stemmed from the flying type, terrestrial animals from crawling forms.

The anonymous plates in De anima brutorum commentaria demonstrate the extent to which evolutionary ideas circulated during the Enlightenment, when drawing and carving were valuable means of transmitting progressive ideas to readers with minds open to novel concepts.

Fausto Barbagli is curator at the Natural History Museum of Florence University, Via Romana 17, I-50125 Florence, Italy.

e-mail: fausto.barbagli@unifi.it

See www.nature.com/darwin/index. html for more on Darwin.

Corrections
In the Book Review 'Amphibian
mystery misread' by Alan Pounds
and Karen Masters (Nature 462,
38-39; 2009) the sentence "Collins
and Crump's selection of published
work and quoted opinions
downplays such links" should
have read "Collins and Crump's
assessment of published work
and the opinions that they quote
downplay such links."
In Alison Abbott's Arts Review
'Florence's observatory restored'
(Nature 462, 40; 2009), "Pietro
Leopardo" should have read "Pietro
Leopoldo".

\section{Corrections}

In the Book Review 'Amphibian mystery misread' by Alan Pounds and Karen Masters (Nature 462, 38-39; 2009) the sentence "Collins and Crump's selection of published rk and quoted opinions and the opinions that they quot downplay such links." Leopoldo". 